\title{
Sistemler Akademik Başarı Testi: Geçerlik ve Güvenirlik Çalışması*
}

\section{Systems Academic Achievement Test: Validity and Reliability Study}

\section{Gonca KEÇECi'}

Pelin YILDIRIM ${ }^{2}$

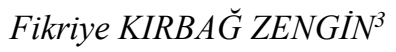

Alıntılama: Keçeci, G., Yıldırım, P., \& Kırbă̆ Zengin, F. (2019). Sistemler akademik başarı testi: Geçerlik ve güvenirlik çalışması. Ulusal Eğitim Akademisi Dergisi (UEAD), 3(1), 96-114.

Geliş tarihi:

17 Ocak 2019

Kabul tarihi:

25 Nisan 2019

(C) UEAD 2019

Tüm hakları saklıdır.
Özet: Bu çalışma ile ortaokul öğrencilerinin 6. sınıf Fen Bilimleri dersinin öğretim programında bulunan vücudumuzdaki sistemler ünitesindeki solunum sistemi, dolaşım sistemi, destek ve hareket sistemi konu başlıklarına ilişkin başarılarını ölçmek amacıyla bir ölçme aracı geliştirilmesi amaçlanmıştır. Çalışma kapsamında 36 tane çoktan seçmeli soru hazırlanmış ve kapsam geçerliğinin tespiti için dört öğretim üyesi, bir öğretim elemanı ve iki fen bilgisi öğretmeni, toplam 7 uzmanın görüşüne sunulmuştur. Uzman görüşleri doğrultusunda, testteki soruların bazıları düzeltilerek, bazıları ise testten çıkartılarak soru sayısı 30'a düşürülmüştür. Uzman görüşleri doğrultusunda düzeltilen testin yapı geçerliğini temin etmek için madde analizi yapılmıştır. Ön pilot uygulamaya 89'u kız, 69'u erkek olmak üzere toplam 158 ögrenci katılmıştır. Ayırt ediciliği 0.19 ve daha küçük olan 7 maddenin testten çıkarılması sonucuna varıldıktan sonra, son şekli verilen ölçek 23 madde olarak pilot uygulamaya hazır hale getirilmiştir. Pilot uygulama ile 23 sorudan oluşan test, 47 'si kız, 53'ü erkek olmak üzere 100 kişiden oluşan yedinci ve sekizinci sınıf öğrencilerine tatbik edilerek tekrar madde analizi yapılmıştır. Yapılan madde analizi sonucunda geliştirilen Sistemler Başarı Testi’nin güvenirliğiyle ilgili olarak Cronbach Alpha katsayıs1 .83, Spearman Brown iki yarı test korelasyon değeri ise .81 olarak hesaplanmış, geçerli ve güvenilir bir test geliştirilmiştir.

Anahtar kelimeler: sistemler akademik başarı testi, geçerlik, güvenirlik, ortaokul öğrencileri.

\footnotetext{
* Bu çalışma “Mobil artırılmış gerçeklik teknolojisi ile yapılan fen öğretiminin ortaokul öğrencilerinin fen ve
} teknolojiye yönelik tutumlarına ve akademik başarılarına etkisi" isimli tezin ilgili kısımlarından üretilmiştir.

1 Fırat Üniversitesi Eğitim Fakültesi, gkececi@firat.edu.tr, ORCID ID: 0000-0002-2582-3850.

${ }^{2}$ Firat Üniversitesi, yildirim.pelin92@gmail.com, ORCID ID: 0000-0003-4425-2472.

3 Firat Üniversitesi Eğitim Fakültesi, fzengin@firat.edu.tr, ORCID ID: 0000-0002-0547-8746. 
Received:

17 January 2019

Accepted:

25 April 2019

(C) UEAD 2019

All rights reserved.

\begin{abstract}
With this study, it was aimed to develop a measurement tool in order to the respiratory system, circulatory system, support and movement system topics in the systems unit of our body which is included in the curriculum of 6th grade Science course and to measure their achievement of secondary school students. 36 multiple choice question items were prepared within the scope of the study and four faculty members, one instructor and two science teachers were presented to the opinion a total of 7 experts to determine the scope validity. In line with expert opinions, some of the questions in the test were corrected and some of them were removed from the test and the number of questions was reduced to 30 . In order to ensure the construct validity of the test, which was corrected according to expert opinions, substance analysis was performed. A total of 158 students, 89 of whom are girl and 69 are boy participated in the pre-pilot application. After the conclusion was made that 7 substances whose discrimination was 0.19 and smaller were removed from the test, the final shape was made ready to pilot application as 23 substances. Test with 23 questions with pilot application was applying to the seventh and eighth grade students, consisting of 100 students, including 47 girls and 53 boys, and the substance analysis was repeated. Regarding the reliability of the Systems Achievement Test developed as a result of the substance analysis, Cronbach Alpha coefficient was calculated as .83, and Spearman Brown two half test correlation value was calculated as .81 , a valid and reliable test was developed.
\end{abstract}

Keywords: systems academic achievement test, validity, reliability, secondary school students.

\section{Giriş}

Tarım toplumundan; sosyo-ekonomik, teknolojik, sosyo-politik, sosyo-kültürel alanlar ve değerler sistemi gibi temel farklılıklar neticesinde bilgi toplumuna geçildiği bu süreçte, insan doğasını meydana getiren özellikler, eğitim aracılığıyla değiştirilebilir. Eğitim; bireylerin davranışlarında yaşantıları aracılığıyla ve kasıtlı bir şekilde istendik değişmeleri oluşturma süreci olarak tanımlanabilir (Gültekin, 2017). Eğitimin, istenilen davranışları kazandırmada ne derece etkili olduğunun belirlenmesi ve süreç içerisinde bireylere bilgi, beceri, davranış, değerler gibi önemli sayılan nitelikler açısından ne gibi değişiklikler sağladığının tespit edilmesi; eğitim sisteminin yenilenmesi, geliştirilmesi, var olan noksanların saptanması ve yeterli düzeyde geri bildirimin verilmesi adına oldukça önemli bir ihtiyaç olup, bu ihtiyaç ölçme ve değerlendirme yardımı ile karşılanabilmektedir.

Öğrenme ve öğretme sürecinin en etkili unsurlarından olan ölçme ve değerlendirme kavramları her ne kadar ayrı kavramlar olsa da birbirlerinin tamamlayıcısı niteliğindedir (Yıldırım, 1983). Ölçme, bir niteliğin gözlenmesi neticesinde ulaşılan gözlem sonuçlarının sayılar veya semboller kullanılarak gösterilmesidir (Turgut, 1977). Ölçme, bir nesnenin veya bir bireyin, belirli bir kaliteye veya özelliğe ne denli sahip olduğunun tespit edilmesi işlemi olup, bu süreçte ölçülen değişkenler; zamana, duruma veya bireye göre farklılıklar gösteren ve bireylerde bulunduğu kabul edilen özelliklerdir (Kan, 2006). Değerlendirme ise, ölçme işlemi neticesinde ulaşılan sonuçların bir ölçütle mukayese edilmesi sonucunda bir karara varılmasıdır. (Bahar, Nartgün, Durmuş ve Bıçak, 2012). Dolayısıyla ölçme sonucu ve ölçüt değerlendirme yapmanın iki temel öğesidir. 


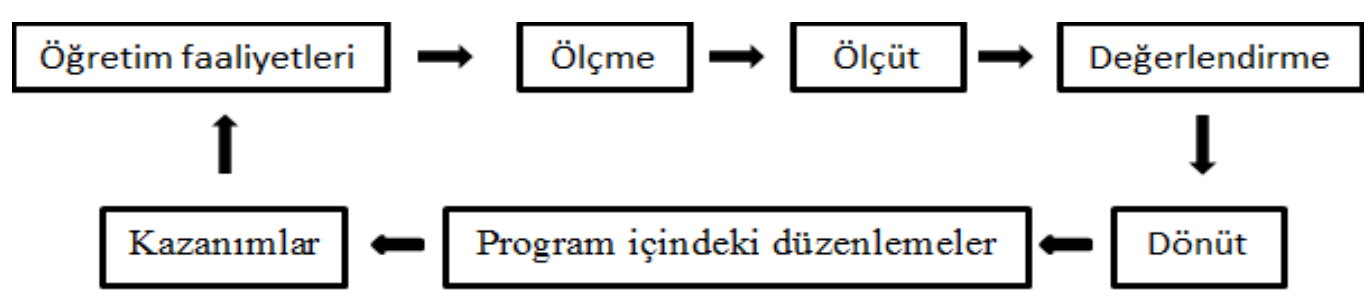

Şekil 1. Öğretim Sürecinde Ölçme ve Değerlendirmenin Yeri (Başol, 2015, s. 4)

Fen eğitiminde öğrencilerin eğitim-öğretim sürecinde hedeflenen kazanımlara ne ölçüde sahip olduklarının belirlenmesi ve belirlenen konuya ilişkin başarı düzeylerinin somut bir şekilde ortaya konulması için geçerli ve güvenilir ölçme araçlarına gereksinim vardır (Gönen, Kocakaya ve Kocakaya, 2011). Yazılı ve sözlü sınavlar, eşleştirmeli ve doğru-yanlış maddelerinden oluşan testler, anketler, kısa cevaplı testler, iki ya da üç aşamadan oluşan testler bu amaçlar doğrultusunda eğitim alanında kullanılan ölçme ve değerlendirme araçlarıdır (Şimşek, 2007). Günümüzde hem bireylere öğretilen bilgilerin yoklanmasına imkân tanıyarak bireylerin ilgili konuya ilişkin başarılarının hem de bilgi, kavrama ve uygulama düzeyindeki davranışların ölçülmesinde sıkça kullanılan çoktan seçmeli testler, mülakatlardan sonra yaygın olarak kullanılan değerlendirme metotlarından biridir (Ogan Bekiroğlu, 2004). Çoktan seçmeli testler, bireylerin yorumlama, çözümleme, değerlendirme ve yargılama gibi üst düzey zihinsel becerilerini ölçmede tam anlamıyla etkili olamasa da var olan kavram yanılgılarının ve başarı düzeylerinin belirlenmesinde tercih edilen değerlendirme metotlarındandır (Küçükahmet, 2002).

Ülkemizde Fen Bilimleri dersine yönelik olarak geçerli, güvenilir ve çoktan seçmeli sorulardan oluşan bir başarı testinin geliştirilmesinin amaç edinildiği çalışmalara sıkça rastlanmaktadır. Araştırma kapsamında geliştirilen başarı testleri Vücudumuzun Bilmecesini Çözelim, Maddenin Değişimi, Maddenin Tanecikli Yapısı, Çözeltiler, Kuvvet ve Hareket, İş ve Enerji gibi çeşitli konu ve ünitelere yöneliktir (Açıkgöz ve Karslı, 2015; Akbulut ve Çepni, 2013; Demir, Kızılay ve Bektaş, 2016; Kenan ve Özmen, 2014; Öcal, 2014; Saraç, 2018; Şener \& Taş, 2017). Bu çalışmalardan biri Saraç (2018) tarafından gerçekleştirilmiş ve araştırma ile 5. sınıf Fen Bilimleri dersinin içeriğinde yer alan 'Maddenin Değişimi' ünitesine iliş̧kin bir başarı testinin geliştirilmesi amaçlanmıştır. Çalışma kapsamında 55 tane çoktan seçmeli soru hazırlanmış ve kapsam geçerliğinin tespiti için üç öğretim üyesi ve beş fen bilgisi öğretmeni olmak üzere toplam 8 uzmanın görüşüne sunulmuştur. Uzman görüşleri doğrultusunda 30 soruya düşürülen test, 230 ortaokul öğrencisine uygulanmıştır. Yapılan madde analizi sonucunda ayırt ediciliği 0.30'un altında olan iki sorunun testten çıkarılması ile son halini alan ve 28 sorudan oluşan testin ortalama güçlük indeksi 0.501 , ortalama ayırt edicilik indeksi 0.488 ve Kuder Richardson (KR)-20 güvenirlik katsayısı 0.714 olarak hesaplanmıştır. Demir, Kızılay ve Bektaş (2016) tarafından gerçekleştirilen başka bir çalışma ile 7. sınıf Fen Bilimleri dersinin içeriğinde yer alan çözeltiler konusuna ilişkin bir başarı testinin geliştirilmesi amaçlanmıştır. Çalışma kapsamında öğretim programında bulunan kazanımlara yönelik bir belirtke tablosu oluşturularak 40 tane çoktan seçmeli soru hazırlanmış ve uzman görüşüne sunulmuştur. Uzman görüşleri doğrultusunda 20 soruya düşürülen test, 7.sınıf öğrencisi olan 100 kişiye uygulanmıştır. Yapılan analizler neticesinde 20 sorudan oluşan testin ortalama ayırt edicilik indeksi 0.485 , Cronbach alfa güvenirlik katsayısı 0.738 olarak hesaplanmış, geçerli ve güvenilir bir test geliştirilmiştir.

Alan yazında solunum sistemi, dolaşım sistemi, destek ve hareket sistemi konularını içeriğinde barındıran yalnızca bir tane başarı testi geliştirilmiştir (Öcal, 2014). Gerek bu noktadaki sınırlılığı gidererek alan yazına katkı sağlamak gerekse öğrencilerin belirlenen konuya ilişkin 
anlama seviyelerini ortaya çıkarmak, başarılarını ölçmek ve değerlendirmek amacıyla geçerlik ve güvenirlik koşullarını sağlayan bir başarı testi geliştirilmesi amaçlanmıştır.

\section{Yöntem}

Gerçekleştirilen çalışma ile öğrencilerin solunum sistemi, dolaşım sistemi, destek ve hareket sistemi konularına ilişkin anlama seviyelerini ortaya çıkarmak, başarılarını ölçmek ve değerlendirmek amacıyla geçerlik ve güvenirlik koşullarını sağlayan bir başarı testinin geliştirilmesi amaç edinilmiştir. Geçerli ve güvenilir bir başarı testi oluşturmak adına Crocker ve Algina (1986)'ya ait test geliştirme adımları izlenmiştir. İlk adımda geliştirilen testten elde edilecek puanların hangi amaçlar doğrultusunda kullanılacağı tayin edilmiştir. Akabinde testin etki alanını tanıtan davranışlar ve testte yer alması muhtemel maddelerin etkileri belirlenmiştir. Sonraki adımda madde havuzu oluşturulmuş ve testte yer alması muhtemel maddelerin detaylı olarak incelenmesi adına uzman görüşüne başvurulmuştur. Uzman görüşleri doğrultusunda düzeltilen test, 158 öğrenciye ön pilot uygulaması şeklinde gerçekleştirilmiştir. Ön pilot uygulama ile ulaşılan veriler neticesinde madde analizi yapılmış ve kriterlere uygun olmayan maddeler testten çıkarılmıştır. Son şekli verilen ve 23 maddeden oluşan test, pilot uygulama ile 100 öğrenciye uygulanmış, akabinde tekrar madde analizi yapılmış ve test istatistikleri belirlenmiştir. Son olarak ise ulaşılan test puanlarına ilişkin yönerge geliştirmiştir.

\section{Araştırma Grubu}

Araştırma, 2017-2018 y1lında Elazı̆̆ il merkezinde öğrenim gören, basit rastgele örneklem tekniğiyle seçilen 258 (ön pilot uygulama 158, pilot uygulama 100) ilköğretim yedinci ve sekizinci sınıf öğrencileri ile gerçekleştirilmiştir. Araştırma kapsamında geliştirilen test 6 . sınıf Fen Bilimleri dersinin öğretim programında bulunan vücudumuzdaki sistemler ünitesine yönelik olmasına rağmen ilköğretim 6. sınıf öğrencilerinin bu üniteyi işlememiş olmalarından kaynaklanabilecek, soruları bilerek cevaplamama veya boş bırakma ihtimallerini minimum seviyede tutmak amaciyla araştırmanın çalışma grubuna 6. sınıf öğrencileri dâhil edilmemiş, örneklem ilköğretim yedinci ve sekizinci sınıf öğrencilerinden oluşturulmuştur.

\section{Test Geliştirme Süreci}

Çalışma kapsamında vücudumuzdaki sistemler ünitesindeki solunum sistemi, dolaşım sistemi, destek ve hareket sistemi konu başlıklarını içeriğinde barındıran başarı testi geliştirilmesinde, Crocker ve Algina (1986)'ya ait test geliştirme adımları izlenmiştir. Bu adımlar;

- Testten elde edilecek puanların hangi amaçlar doğrultusunda kullanılacağının tayin edilmesi,

- Yapı hakkında bilgiler veren ve etki alanını tanıtan davranışların belirlenmesi,

- Testte yer alması muhtemel maddelerin belirtke tablosu aracılığıyla ağırlıklarının belirlenmesi,

- Madde havuzunun oluşturulmasi,

- Testte yer almasi muhtemel maddelerin detaylı olarak incelenmesi (redaksiyon),

- Deneme formunun uygulanabilecek duruma gelmesi,

- Testin, araştırma amacına uygun olan örnekleme ön denemesinin gerçekleştirilmesi,

- Madde istatistiklerinin belirlenerek, kriterlere uygun olmayan maddelerin çıkarılması,

- Test istatistiklerinin belirlenerek, kriterlere uygun olmayan maddelerin çıkarılması,

- Test puanlarına yönelik olarak yönergenin geliştirilmesi şeklinde maddeleştirilebilir. 
Çalışma kapsamında öğrencilerin belirlenen konuya ilişkin anlama seviyelerini ortaya çıkarmak, başarılarını ölçmek ve değerlendirmek amacıyla başarı testi geliştirilmesi amaçlanmıştır.

Sindirim sistemi gibi bireylerin daha önce karşılaşmadığı soyut kavramları içeriğinde barındıran fen konuların öğretilmesi noktasında, öğrencilerin soyut kavramları öğrenmekte zorlanmaları, öğrencilerde soyut kavramların yanlış öğrenilmesinden kaynaklanan kavram yanılgılarının meydana gelmesi (Ekiz, 2015), meydana gelen kavram yanılgılarının öğrencileri yeni konuları öğrenmelerini zorlaştırması (Gülçiçek, 2002; Koray ve Tatar, 2003; Selvi ve Yakışan, 2004; Yürük ve Çakır, 2004) gibi çeşitli nedenler, geliştirilmesi hedeflenen başarı testinin içeriğinde vücudumuzdaki sistemler ünitesinde yer alan hücre konusu haricindeki konuları barındırmasında etkili olmuştur.

Geliştirilen testin kapsam geçerliğini sağlaması adına 6. sınıf vücudumuzdaki sistemler ünitesi içerisinde yer alan kazanımların (Talim ve Terbiye Kurulu Başkanlığı (TTKB), 2013) konulara göre dağılımına ilişkin belirtke tablosu hazırlanmıştır. İlköğretim 6. sınıf vücudumuzdaki sistemler ünitesi; hücre, solunum sistemi, dolaşım sistemi, destek ve hareket sistemi konu başlıklarını ihtiva eden 14 kazanımdan oluşmaktadır. 14 kazanım içerisindeki 3 kazanım hücre, 3 kazanım solunum sistemi, 6 kazanım dolaşım sistemi, 2 kazanım ise destek ve hareket sistemi konu başlıklarına yöneliktir. Çalışma kapsamında hücre konu başlığı dışındaki kazanımları kapsayacak biçimde 36 tane çoktan seçmeli soru hazırlanmıştır.

Hazırlanan 36 soru; madde kökü, soruda bulunan çeldiriciler, soruların kazanımları kapsama durumu açısından dört öğretim üyesi, bir öğretim elemanı ve iki fen bilgisi öğretmeni olmak üzere toplam 7 uzmanın görüşüne sunulmuştur. Uzman görüşleri doğrultusunda, madde köklerinin ve sorularda kullanılan resimlerin puntolarının yeterli derecede büyük olmaması, soru ifadelerinin bulanık olması, testte bulunan bazı cümlelerin öğrenci grubunun bilişsel seviyesine elverişli olmaması, birtakım soruların ünite kapsamındaki kazanımlar ile örtüşmemesi gibi çeşitli sebeplerden dolayı testteki soruların bazıları düzeltilerek, bazıları ise testten çıkartılarak soru sayısı 30'a düşürülmüştür.

Uzman görüşleri doğrultusunda onarılan testin yapı geçerliliğini yani soruların daha nitelikli olmasını temin etmek için madde analizi yapılmıştır (Turgut, 1992).

Düzenlenen ölçek, 89’u kız, 69'u erkek olmak üzere toplam 158 öğrenciye ön pilot uygulaması şeklinde gerçekleştirilmiştir. Öğrencilerin testten aldıkları puanlar başarı sırasına göre sıraya konularak, alt ve üst grubu belirlemek amaciyla alttan ve üstten toplam sayının \% 27 'sine karşılık gelen 43 kişi seçilmiştir. Ulaşılan veriler neticesinde madde analizi yapıllmış, madde ayırt edicilik indeksleri 0.40 ve daha büyük olan maddeler çok iyi, 0.30-0.39 arasında olan maddeler oldukça iyi olarak nitelendirilmiş, 0.20-0.29 arasında olan maddelerde düzeltme ve geliştirilme yoluna gidilmiş, 0.19 ve daha küçük olan maddeler ise testten çıkarılmıştır (Turgut, 1995). Ön pilot uygulama için tayin edilen 30 sorunun ünite içerisindeki dağılımı; destek ve hareket sistemiyle ilgili 10 soru, solunum sistemiyle ilgili 7 soru, dolaşım sistemiyle ilgili 13 soru şeklindedir. Ön pilot uygulamayı müteakiben geçerlik ve güvenirlik çalışmaları neticesinde test 23 madde olarak tayin edilmiştir. Pilot uygulama ile 23 sorudan oluşan test, 100 kişiden oluşan yedinci ve sekizinci sınıf öğrencilerine uygulanarak tekrar madde analizi yapılmıştır. Çalışma süreci boyunca ulaşılan veriler SPSS 22 paket programı aracılığıyla çözümlenerek, geliştirilen testin geçerlik ve güvenirlik çalışmalarına yönelik incelemeler yapılmıştır.

\section{Bulgular}


Araştırmanın bu bölümünde; 6. sınıf Fen Bilimleri dersinin içeriğinde yer alan vücudumuzdaki sistemler ünitesi için geliştirilen başarı testinin geçerlik ve güvenirlik çalışmalarına ilişkin sayısal verilere yer verilmiştir.

Ön pilot uygulamada başarı testinde yer alan maddelerin konulara göre dağılımına ilişkin belirtke tablosuna Tablo 1'de yer verilmiştir.

Tablo 1. Ön Pilot Uygulamada Başarı Testinde Yer Alan Maddelerin Konulara Göre Dă̆llımına Ilişkin Belirtke Tablosu

\begin{tabular}{|c|c|c|c|}
\hline Konular & Kazanımlar & Maddeler & $\begin{array}{c}\text { Kazanım } \\
\text { sayısı }\end{array}$ \\
\hline \multirow{2}{*}{$\begin{array}{l}\text { Destek ve Hareket } \\
\text { Sistemi }\end{array}$} & $\begin{array}{l}\text { Destek ve hareket sistemine ait yapıları açıklar ve görevlerini } \\
\text { belirterek örnekler verir. }\end{array}$ & $\begin{array}{c}1-2-5-6-9- \\
11-15-18- \\
29 \\
\end{array}$ & 9 \\
\hline & $\begin{array}{l}\text { Destek ve hareket sisteminin sağlığını korumak için yapılması } \\
\text { gerekenleri araştırır ve sunar. }\end{array}$ & 14 & 1 \\
\hline \multirow{3}{*}{ Solunum Sistemi } & $\begin{array}{l}\text { Solunum sistemini oluşturan yap1 ve organları model üzerinde } \\
\text { gösterir. }\end{array}$ & $3-7-13-19$ & 4 \\
\hline & $\begin{array}{l}\text { Akciğerlerin yapısını açıklar ve alveol-kılcal damar arasındaki } \\
\text { gaz alışverişini model üzerinde gösterir. }\end{array}$ & $4-22$ & 2 \\
\hline & $\begin{array}{l}\text { Solunum sisteminin sağlığını korumak için yapılması gerekenleri } \\
\text { araştırma verilerine dayalı olarak tartışı. }\end{array}$ & 16 & 1 \\
\hline \multirow{5}{*}{ Dolaşım Sistemi } & $\begin{array}{l}\text { Dolaşım sistemini oluşturan yapı ve organları görevleri ile birlikte } \\
\text { açıklar. }\end{array}$ & $\begin{array}{l}8-12-17-21- \\
27 \\
\end{array}$ & 5 \\
\hline & Büyük ve küçük kan dolaşımını şema üzerinde gösterir. & $23-24-26$ & 3 \\
\hline & Kanın yapı ve görevlerini kavrar. & $10-20$ & 2 \\
\hline & Kan grupları arasındaki kan alışverişini kavrar. & 30 & 1 \\
\hline & $\begin{array}{l}\text { Dolaşım sisteminin sağlığını korumak için yapılması gerekenleri } \\
\text { araştırma verilerine dayalı olarak tartışır. }\end{array}$ & $25-28$ & 2 \\
\hline
\end{tabular}

Tablo 1 incelendiğinde ön pilot uygulamada Sistemler Başarı Testindeki maddelerden 1-25-6-9-11-14-15-18 ve 29 numaral1 10 maddenin destek ve hareket sisteminde, 3-4-7-13-16-19 ve 22 numaral1 7 maddenin solunum sisteminde, 8-10-12-17-20-21-23-24-25-26-27-28 ve 30 numaralı 13 maddenin ise dolaşım sisteminde yer alan kazanımlara yönelik olduğu görülmektedir.

\section{Testin Geçerlik Çalışmalarına Yönelik Bulgular}

Testte yer alan maddelerin yapı geçerliğinin sağlanması amacıyla madde analizi yapılmıştır. Ön pilot uygulamaya katılan 158 öğrencinin testten aldıkları puanlar başarı sırasına göre sıralanarak, alt ve üst grubu belirlemek amacıyla alttan ve üstten toplam sayının \% 27'sine karş1lık gelen kırk üçer kişi seçilmiştir. Madde analizi sonucunda hesap edilen madde ayırt edicilik indekslerine ve güçlük derecelerine Tablo 2'de yer verilmiştir.

Tablo 2. Ön Pilot Uygulamada Başarı Testinde Bulunan Maddelerin Güçlük Dereceleri (p) ve Ayırt Edicilik Indeksleri (d)

\begin{tabular}{cccccccccc}
\hline Sorular & Gruplar & A & B & C & D & Boş & Dolu & p & d \\
\hline \multirow{2}{*}{$\mathbf{1}$} & Üst & - & 1 & 39 & 3 & 0 & 43 & & 0.55 \\
\cline { 2 - 10 } & Alt & 6 & 6 & 16 & 15 & 0 & 43 & 0.62 & \\
\hline
\end{tabular}


Keçeci \& Ylldırım \& Kırbağ Zengin (2019)

\begin{tabular}{|c|c|c|c|c|c|c|c|c|c|}
\hline \multirow{2}{*}{2} & Üst & 1 & - & - & 42 & 0 & 43 & \multirow{2}{*}{0.94} & \multirow{2}{*}{0.06} \\
\hline & Alt & 3 & - & 1 & 39 & 0 & 43 & & \\
\hline \multirow{2}{*}{3} & Üst & - & 43 & - & - & 0 & 43 & \multirow{2}{*}{0.87} & \multirow{2}{*}{0.25} \\
\hline & Alt & 6 & 32 & 3 & 2 & 0 & 43 & & \\
\hline \multirow{2}{*}{4} & Üst & - & 2 & - & 41 & 0 & 43 & \multirow{2}{*}{0.76} & \multirow{2}{*}{0.37} \\
\hline & Alt & 4 & 11 & 3 & 25 & 0 & 43 & & \\
\hline \multirow{2}{*}{5} & Üst & - & 4 & 38 & 1 & 0 & 43 & \multirow{2}{*}{0.81} & \multirow{2}{*}{0.13} \\
\hline & Alt & 2 & 7 & 32 & 2 & 0 & 43 & & \\
\hline \multirow{2}{*}{6} & Üst & 38 & 3 & 1 & 1 & 0 & 43 & \multirow{2}{*}{0.60} & \multirow{2}{*}{0.55} \\
\hline & Alt & 14 & 17 & 7 & 5 & 0 & 43 & & \\
\hline \multirow{2}{*}{7} & Üst & 3 & 30 & 7 & 3 & 0 & 43 & \multirow{2}{*}{0.50} & \multirow{2}{*}{0.39} \\
\hline & Alt & 9 & 13 & 2 & 9 & 0 & 43 & & \\
\hline \multirow{2}{*}{8} & Üst & 39 & 3 & - & 1 & 0 & 43 & \multirow{2}{*}{0.59} & \multirow{2}{*}{0.62} \\
\hline & Alt & 12 & 16 & 9 & 6 & 0 & 43 & & \\
\hline \multirow{2}{*}{9} & Üst & 1 & - & 4 & 38 & 0 & 43 & \multirow{2}{*}{0.61} & \multirow{2}{*}{0.53} \\
\hline & Alt & 8 & 7 & 13 & 15 & 0 & 43 & & \\
\hline \multirow{2}{*}{10} & Üst & 42 & - & 1 & - & 0 & 43 & \multirow{2}{*}{0.69} & 055 \\
\hline & Alt & 18 & 6 & 13 & 6 & 0 & 43 & & 0.J \\
\hline & Üst & 1 & - & 42 & - & 0 & 43 & ( 60 & 055 \\
\hline 11 & Alt & 14 & 6 & 18 & 5 & 0 & 43 & 0.09 & $0.5 J$ \\
\hline & Üst & - & 43 & - & - & 0 & 43 & & \\
\hline 12 & Alt & 5 & 26 & 3 & 9 & 0 & 43 & 0.00 & נ \\
\hline & Üst & 43 & - & - & - & 0 & 43 & 002 & 012 \\
\hline 10 & Alt & 37 & - & 4 & 2 & 0 & 43 & 0.30 & $0.1 J$ \\
\hline 14 & Üst & - & - & - & 43 & 0 & 43 & 084 & 030 \\
\hline 14 & Alt & 2 & 8 & 2 & 30 & 0 & 43 & 0.07 & 0.50 \\
\hline 15 & Üst & 2 & 1 & 6 & 34 & 0 & 43 & 053 & 051 \\
\hline 15 & Alt & 9 & 9 & 12 & 13 & 0 & 43 & 0.33 & 0.01 \\
\hline & Üst & - & 2 & 40 & 1 & 0 & 43 & O & 707 \\
\hline 10 & Alt & 3 & 9 & 28 & 3 & 0 & 43 & 0.19 & 0.21 \\
\hline 17 & Üst & 41 & - & - & 2 & 0 & 43 & 002 & $0 \Omega 4$ \\
\hline 11 & Alt & 39 & 1 & - & 3 & 0 & 43 & 0.95 & 0.04 \\
\hline 10 & Üst & 40 & - & 3 & - & 0 & 43 & 060 & 048 \\
\hline 10 & Alt & 20 & 7 & 11 & 5 & 0 & 43 & 0.0 & 0.70 \\
\hline 10 & Üst & 5 & 35 & 2 & 1 & 0 & 43 & 17 & 067 \\
\hline . & Alt & 18 & 6 & 10 & 9 & 0 & 43 & 0.41 & 0.01 \\
\hline
\end{tabular}


Sistemler Akademik Başarı Testi: Geçerlik ve Güvenirlik Çalışması

\begin{tabular}{|c|c|c|c|c|c|c|c|c|c|}
\hline \multirow{2}{*}{20} & Üst & - & - & - & 43 & 0 & 43 & \multirow{2}{*}{0.80} & \multirow{2}{*}{0.39} \\
\hline & Alt & 4 & 3 & 10 & 26 & 0 & 43 & & \\
\hline \multirow{2}{*}{21} & Üst & 1 & - & 42 & - & 0 & 43 & \multirow{2}{*}{0.70} & \multirow{2}{*}{0.53} \\
\hline & Alt & 12 & 6 & 19 & 6 & 0 & 43 & & \\
\hline \multirow{2}{*}{22} & Üst & - & 43 & - & - & 0 & 43 & \multirow{2}{*}{0.93} & \multirow{2}{*}{0.13} \\
\hline & Alt & 1 & 37 & 1 & 4 & 0 & 43 & & \\
\hline \multirow{2}{*}{23} & Üst & 2 & 40 & 1 & - & 0 & 43 & \multirow{2}{*}{0.62} & \multirow{2}{*}{0.60} \\
\hline & Alt & 13 & 14 & 8 & 10 & 0 & 43 & & \\
\hline \multirow{2}{*}{24} & Üst & 15 & 6 & 6 & 16 & 0 & 43 & \multirow{2}{*}{0.22} & \multirow{2}{*}{0.25} \\
\hline & Alt & 4 & 11 & 10 & 18 & 0 & 43 & & \\
\hline \multirow{2}{*}{25} & Üst & 36 & 1 & 4 & 2 & 0 & 43 & \multirow{2}{*}{0.67} & \multirow{2}{*}{0.32} \\
\hline & Alt & 22 & 5 & 11 & 5 & 0 & 43 & & \\
\hline \multirow{2}{*}{26} & Üst & 6 & 33 & 2 & 2 & 0 & 43 & \multirow{2}{*}{0.55} & \multirow{2}{*}{0.41} \\
\hline & Alt & 14 & 15 & 7 & 7 & 0 & 43 & & \\
\hline \multirow{2}{*}{27} & Üst & 3 & - & 39 & 1 & 0 & 43 & \multirow{2}{*}{0.86} & \multirow{2}{*}{0.09} \\
\hline & Alt & 5 & 1 & 35 & 2 & 0 & 43 & & \\
\hline \multirow{2}{*}{28} & Üst & 1 & 8 & 3 & 31 & 0 & 43 & \multirow{2}{*}{0.45} & \multirow{2}{*}{0.53} \\
\hline & Alt & 9 & 16 & 10 & 8 & 0 & 43 & & \\
\hline \multirow{2}{*}{29} & Üst & 6 & 7 & 15 & 15 & 0 & 43 & \multirow{2}{*}{0.26} & \multirow{2}{*}{0.16} \\
\hline & Alt & 10 & 9 & 16 & 8 & 0 & 43 & & \\
\hline \multirow{2}{*}{30} & Üst & - & 3 & 1 & 39 & 0 & 43 & \multirow{2}{*}{0.59} & \multirow{2}{*}{0.62} \\
\hline & Alt & 6 & 16 & 9 & 12 & 0 & 43 & & \\
\hline
\end{tabular}

Tablo 2 incelendiğinde, testin güçlük indekslerinin .22 ile .94 arasında, ayırt edicilik indekslerinin ise .04 ile .67 arasında değiştiği görülmektedir. Madde ayırt edicilik indeksleri 0.40 ve daha büyük olan maddeler çok iyi, 0.30-0.39 arasında olan maddeler oldukça iyi olarak nitelendirilmiş, 0.200.29 arasında olan maddelerde düzeltme ve geliştirilme yoluna gidilmiş, 0.19 ve daha küçük olan maddeler ise testten çıkarılmıştır (Tekin, 2010; Turgut, 1995). Bu doğrultuda ayırt edicilik indeksi 0.40 ve büyük olan 1-6-8-9-10-11-15-18-19-21-23-26-28 ve 30 numaralı 14 maddenin çok iyi, ayırt edicilik indeksi 0.30- 0.39 arasında olan 4-7-12-14-20 ve 25 numaralı 6 maddenin oldukça iyi madde özelliğine sahip olduğu tespit edilmiş ve bu maddelere herhangi bir değişikliğe gidilmeyerek testte yer verilmiştir. Maddelerin anlaşılır bir biçimde ifade edilememesi, ünite kapsamındaki kazanımlar ile tam anlamıyla örtüşmemesi, farklı tefsirlere açık olması gibi çeşitli sebeplerden dolayı ayırt edicilik indeksi 0.20 ile 0.29 arasında olan 3-16 ve 24 numaralı 3 madde üzerinde bu sebepleri ortadan kaldıracak düzenlemeler yapılmış ve teste dahil edilmiştir. Ayırt ediciliği 0.19 ve daha küçük olan 2-5-13-17-22-27 ve 29 numaralı 7 maddenin testten çıkarılması sonucuna varılmıştır. Son şekli verilen ölçek 23 madde olarak pilot uygulamaya hazır hale getirilmiştir.

Pilot uygulamada başarı testinde yer alan maddelerin konulara göre dağılımına ilişkin belirtke tablosuna Tablo 3'de yer verilmiştir. 
Tablo 3. Pilot Uygulamada Başarı Testinde Yer Alan Maddelerin Konulara Göre Dağılımına Ilişkin Belirtke Tablosu

\begin{tabular}{|c|c|c|c|}
\hline Konular & Kazanımlar & Maddeler & $\begin{array}{c}\text { Kazanım } \\
\text { sayısı }\end{array}$ \\
\hline \multirow{2}{*}{$\begin{array}{l}\text { Destek ve Hareket } \\
\text { Sistemi }\end{array}$} & $\begin{array}{l}\text { Destek ve hareket sistemine ait yapıları açıklar ve görevlerini } \\
\text { belirterek örnekler verir. }\end{array}$ & $\begin{array}{l}1-4-7-9-12- \\
14\end{array}$ & 6 \\
\hline & $\begin{array}{l}\text { Destek ve hareket sisteminin sağlığını korumak için yapılması } \\
\text { gerekenleri araştırır ve sunar. }\end{array}$ & 11 & 1 \\
\hline \multirow{3}{*}{ Solunum Sistemi } & $\begin{array}{l}\text { Solunum sistemini oluşturan yap1 ve organları model üzerinde } \\
\text { gösterir. }\end{array}$ & $2-5-15$ & 3 \\
\hline & $\begin{array}{l}\text { Akciğerlerin yapısını açıklar ve alveol-kılcal damar arasındaki } \\
\text { gaz alışverişini model üzerinde gösterir. }\end{array}$ & 3 & 1 \\
\hline & $\begin{array}{l}\text { Solunum sisteminin sağlığını korumak için yapılması gerekenleri } \\
\text { araştırma verilerine dayalı olarak tartışı. }\end{array}$ & 13 & 1 \\
\hline \multirow{5}{*}{ Dolaşım Sistemi } & $\begin{array}{l}\text { Dolaşım sistemini oluşturan yapı ve organları görevleri ile birlikte } \\
\text { açılar. }\end{array}$ & $6-10-17$ & 3 \\
\hline & Büyük ve küçük kan dolaşımını şema üzerinde gösterir. & $18-19-21$ & 3 \\
\hline & Kanın yapı ve görevlerini kavrar. & $8-16$ & 2 \\
\hline & Kan grupları arasındaki kan alışverişini kavrar. & 23 & 1 \\
\hline & $\begin{array}{l}\text { Dolaşım sisteminin sağlığını korumak için yapılması gerekenleri } \\
\text { araştırma verilerine dayalı olarak tartışı. }\end{array}$ & $20-22$ & 2 \\
\hline
\end{tabular}

Tablo 3 incelendiğinde pilot uygulamada Sistemler Başarı Testindeki maddelerden 1-4-79-11-12 ve 14 numaralı 7 maddenin destek ve hareket sisteminde, 2-3-5-13 ve 15 numaral1 5 maddenin solunum sisteminde, 6-8-10-16-17-18-19-20-21-22 ve 23 numaral1 11 maddenin ise dolaşım sisteminde yer alan kazanımlara yönelik olduğu görülmektedir.

Pilot uygulama ile 23 sorudan oluşan test, 100 kişiden oluşan yedinci ve sekizinci sınıf öğrencilerine tatbik edilerek tekrar madde analizi yapılmıştır. Madde analizi neticesinde ortaya çıkan ayırt edicilik indeksi puanlarına Tablo 4'de yer verilmiştir.

Tablo 4. Pilot Uygulamada Başarı Testinde Bulunan Maddelerin Güçlük Dereceleri (p), Ayırt Edicilik Indeksleri (d), Madde-Toplam Korelasyonları ve t-değerleri

\begin{tabular}{|c|c|c|c|c|c|c|c|c|c|c|c|}
\hline Sorular & Gruplar & $\mathbf{A}$ & B & $\mathbf{C}$ & D & Boş & Dolu & $\mathbf{p}$ & d & $\begin{array}{c}\text { Madde- } \\
\text { Toplam } \\
\text { Korelasyonu }^{1} \\
\end{array}$ & $\begin{array}{c}\mathrm{t} \\
(\mathrm{Alt} \% 27-\ddot{U} s t \\
\% 27)^{2} \\
\end{array}$ \\
\hline \multirow{2}{*}{1} & Üst & - & - & 26 & 1 & 0 & 27 & \multirow{2}{*}{0.70} & \multirow{2}{*}{0.51} & \multirow{2}{*}{0.56} & \multirow{2}{*}{$4.97 * * *$} \\
\hline & Alt & 3 & 4 & 12 & 8 & 0 & 27 & & & & \\
\hline \multirow{2}{*}{2} & Üst & 3 & 24 & - & - & 0 & 27 & \multirow{2}{*}{0.62} & \multirow{2}{*}{0.51} & \multirow{2}{*}{0.53} & \multirow{2}{*}{$4.58 * * *$} \\
\hline & Alt & 9 & 10 & 5 & 3 & 0 & 27 & & & & \\
\hline \multirow{2}{*}{3} & Üst & - & - & - & 27 & 0 & 27 & \multirow{2}{*}{0.62} & \multirow{2}{*}{0.74} & \multirow{2}{*}{0.76} & \multirow{2}{*}{$8.61 * * *$} \\
\hline & Alt & 5 & 10 & 5 & 7 & 0 & 27 & & & & \\
\hline \multirow{2}{*}{4} & Üst & 25 & 2 & - & - & 0 & 27 & \multirow{2}{*}{0.68} & \multirow{2}{*}{0.48} & \multirow{2}{*}{0.51} & \multirow{2}{*}{$4.37 * * *$} \\
\hline & Alt & 12 & 8 & 3 & 4 & 0 & 27 & & & & \\
\hline 5 & Üst & 2 & 15 & 8 & 2 & 0 & 27 & 0.35 & 0.40 & 0.42 & $3.40 * * *$ \\
\hline
\end{tabular}


Sistemler Akademik Başarı Testi: Geçerlik ve Güvenirlik Çalışması

\begin{tabular}{|c|c|c|c|c|c|c|c|c|c|c|c|}
\hline & Alt & 6 & 4 & 11 & 6 & 0 & 27 & & & & \\
\hline \multirow{2}{*}{6} & Üst & 22 & 3 & 1 & 1 & 0 & 27 & \multirow{2}{*}{0.57} & \multirow{2}{*}{0.48} & \multirow{2}{*}{0.48} & \multirow{2}{*}{$4.01 * * *$} \\
\hline & Alt & 9 & 8 & 5 & 5 & 0 & 27 & & & & \\
\hline \multirow{2}{*}{7} & Üst & - & - & 2 & 25 & 0 & 27 & \multirow{2}{*}{0.72} & \multirow{2}{*}{0.40} & \multirow{2}{*}{0.45} & \multirow{2}{*}{$3.68 * * *$} \\
\hline & Alt & 2 & 4 & 7 & 14 & 0 & 27 & & & & \\
\hline \multirow{2}{*}{8} & Üst & 27 & - & - & - & 0 & 27 & \multirow{2}{*}{0.85} & \multirow{2}{*}{0.29} & \multirow{2}{*}{0.41} & \multirow{2}{*}{$3.30 * *$} \\
\hline & Alt & 19 & 2 & 5 & 1 & 0 & 27 & & & & \\
\hline \multirow{2}{*}{9} & Üst & - & - & 27 & - & 0 & 27 & \multirow{2}{*}{0.72} & \multirow{2}{*}{0.55} & \multirow{2}{*}{0.62} & \multirow{2}{*}{$5.70 * * *$} \\
\hline & Alt & 8 & 2 & 12 & 5 & 0 & 27 & & & & \\
\hline \multirow{2}{*}{10} & Üst & - & 27 & - & - & 0 & 27 & \multirow{2}{*}{0.68} & \multirow{2}{*}{0.62} & \multirow{2}{*}{0.67} & \multirow{2}{*}{$6.64 * * *$} \\
\hline & Alt & 5 & 10 & 4 & 8 & 0 & 27 & & & & \\
\hline 1 & Üst & - & 2 & 1 & 24 & 0 & 27 & 77 & (202 & 026 & 2 0 ** \\
\hline 11 & Alt & 2 & 5 & 2 & 18 & 0 & 27 & 0.11 & 0.22 & 0.20 & $2.00 \cdots$ \\
\hline 12 & Üst & - & 1 & 3 & 23 & 0 & 27 & 57 & 55 & 056 & $480 * * *$ \\
\hline 12 & Alt & 5 & 4 & 10 & 8 & 0 & 27 & 0.51 & 0.55 & 0.50 & $4.89 \cdots$ \\
\hline 1 & Üst & - & 1 & 26 & - & 0 & 27 & 001 & קת & م 00 & 007 * \\
\hline 15 & Alt & 2 & 5 & 18 & 2 & 0 & 27 & 0.01 & 0.29 & 0.30 & $2.91 \%$ \\
\hline 19 & Üst & 25 & - & 2 & - & 0 & 27 & $0<0$ & 055 & 050 & $520 \% *$ \\
\hline 14 & Alt & 11 & 3 & 8 & 5 & 0 & 27 & 0.68 & 0.55 & 0.59 & $5.38 \times$ \\
\hline & Üst & 3 & 23 & 1 & - & 0 & 27 & & & & 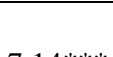 \\
\hline 15 & Alt & 12 & 4 & 6 & 5 & 0 & 27 & 0.50 & 0.10 & 0.10 & $1.14 \%$ \\
\hline & Üst & - & - & - & 27 & 0 & 27 & & & & \\
\hline 16 & Alt & 2 & 1 & 7 & 17 & 0 & 27 & 0.81 & 0.37 & 0.47 & $3.91 * * *$ \\
\hline & Üst & - & - & 27 & - & 0 & 27 & & & & \\
\hline 17 & Alt & 8 & 5 & 9 & 5 & 0 & 27 & 0.66 & 0.66 & 0.70 & $7.21 * * *$ \\
\hline 10 & Üst & - & 27 & - & - & 0 & 27 & 074 & 50 & 50 & $500 * * *$ \\
\hline 18 & Alt & 7 & 13 & 3 & 4 & 0 & 27 & 0.14 & 0.51 & 0.59 & $5.29^{*}+4$ \\
\hline 10 & Üst & 12 & 4 & 3 & 8 & 0 & 27 & 027 & 033 & 037 & $280 * *$ \\
\hline 19 & Alt & 3 & 7 & 5 & 12 & 0 & 27 & 0.21 & 0.33 & 0.31 & $2.89 \cdots$ \\
\hline & Üst & 26 & - & 1 & - & 0 & 27 & 060 & 0,6 & $0<0$ & $607 * * *$ \\
\hline 20 & Alt & 8 & 4 & 9 & 6 & 0 & 27 & 0.62 & 0.66 & 0.69 & $6.87 * * *$ \\
\hline & Üst & 1 & 26 & - & - & 0 & 27 & & & & \\
\hline 21 & Alt & 10 & 8 & 5 & 4 & 0 & 27 & 0.62 & 0.66 & 0.69 & $6.8 / \cdots \cdots$ \\
\hline P & Üst & 3 & 7 & 1 & 16 & 0 & 27 & ד07 & ד07 & > & م \\
\hline 22 & Alt & 7 & 10 & 5 & 5 & 0 & 27 & 0.31 & 0.31 & 0.38 & $2.99 \cdots$ \\
\hline 23 & Üst & - & 1 & - & 26 & 0 & 27 & 0.68 & 0.55 & 0.59 & $5.38 * * *$ \\
\hline
\end{tabular}


Keçeci \& Yıldırım \& Kırbağ Zengin (2019)

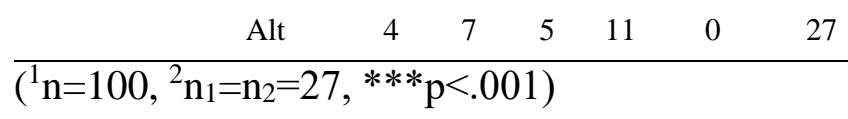

Tablo 4 incelendiğinde 17 maddenin ayırt edicilik indeksinin 0.40 ve üzeri olduğu, 3 maddenin ayırt edicilik indeksinin edicilik indeksinin 0.30- 0.39 arasında olduğu, 3 maddenin ayırt edicilik indeksinin ise 0.20 ile 0.29 arasında olduğu görülmektedir. Ayrıca testte bulunan tüm maddeler için madde-toplam korelasyonlarının .26 ile .76 arasında değiştiği ve 18 maddenin tdeğerlerinin .001 düzeyinde $(\mathrm{p}<.001)$ anlamlı olduğu, 5 maddenin ise .05 düzeyinde $(\mathrm{p}<.05)$ anlamlı olduğu görülmektedir.

\section{Testin Güvenirlik Çalışmalarına Yönelik Bulgular}

Testin güvenirliğinin temin edilmesi adına Cronbach Alpha ve Spearman Brown değerleri hesap edilmiş ve Tablo 5'de gösterilmiştir.

\section{Tablo 5. Alpha ve Spearman Brown İki Yarı Test Güvenirliği ile Toplam Korelasyon Değerleri}

\begin{tabular}{ccc}
\hline & Alpha & İki Yarı Test Korelasyonu \\
\hline Toplam & .83 & .81 \\
\hline
\end{tabular}

Tablo 5 incelendiğinde Sistemler Başarı Testi'nin güvenirliğiyle ilgili olarak Cronbach Alpha katsayısı .83, Spearman Brown iki yarı test korelasyon değeri ise .81 olarak hesap edilmiştir. Cronbach Alpha katsayısının $0,00 \leq \alpha<0,40$ aralığında olması, öğrencilerin testten aldıkları puanların güvenilir olmadığını, $0,40 \leq \alpha<0,60$ aralığında olması, öğrencilerin testten aldıkları puanların düşük olduğunu, $0,60 \leq \alpha<0,90$ aralığında olması, öğrencilerin testten aldıkları puanların oldukça güvenilir olduğunu, $0,90 \leq \alpha<1,00$ aralığında olması ise öğrencilerin testten aldıkları puanların yüksek güvenilirlikte olduğunu yansıtmaktadır (Can, 2014).

\section{Tartışma ve Sonuç}

$\mathrm{Bu}$ çalışma ile öğrencilerin belirlenen konuya ilişkin anlama seviyelerini ortaya çıkarmak, başarılarını ölçmek ve değerlendirmek amacıyla geçerlik ve güvenirlik koşullarını sağlayan bir başarı testinin geliştirilmesi amaç edinilmiştir. Bu hedef doğrultusunda geçerli ve güvenilir bir başarı testi oluşturmak adına test geliştirme adımları takip edilmiştir. Alanyazın incelendiğinde Fen Bilimleri dersine yönelik olarak geliştirilen ölçeklerinde, benzer test geliştirme aşamalarının takip edilmesi sonucunda hazır hale getirildiği görülmektedir (Açıkgöz ve Karsl1, 2015; Akbulut ve Çepni, 2013; Demir, Kızılay ve Bektaş, 2016; Kenan ve Özmen, 2014; Öcal, 2014; Saraç, 2018; Şener \& Taş, 2017).

Testte yer alan maddelerin yapı geçerliğinin sağlanması amacıyla yapılan madde analizi sonucunda, geliştirilen testin nihai halinde yer alan 23 maddeden 17'sinin ayırt edicilik indeksinin 0.40 ve üzeri olduğu görülmektedir. Ulaşılan bu sonuç, testte bir bütün olarak bakıldığında testin genel anlamıyla çok iyi maddelerden oluştuğunun göstergesi niteliğinde olabilir.

Testte bulunan maddelerin madde güçlük indeksi değerleri (p) 0.27 ile 0.85 arasındadır. Testte yer alan 19. maddenin madde güçlük indeksi değerinin 0.27 olması, bu maddenin testteki en zor madde olduğu, öğrencilerin \%27'sinin maddeyi doğru, \%73'ünün ise yanlış cevaplandırdığı sonucunu yansitırken; testte yer alan 8 . maddenin madde güçlük indeksi değerinin 0.85 olması, bu maddenin testteki en kolay madde olduğu, öğrencilerin \%85'inin maddeyi doğru, \%15'inin ise yanlış cevaplandırdığı sonucunu yansıtmaktadır. Kan (2011), testte yer alan maddelerin güçlük 
indeksi değerlerinin, maddelerin uygulanan grup açısından kolaylığı veya zorluğu hakkında çıkarımlarda bulunulmasına yardımcı olduğunu dile getirmiştir. Madde güçlük indeksi değerinin 1.00'e yakın olması, maddeyi doğru cevaplayanların sayısının fazla olduğunu ve maddenin kolay olduğunu; madde güçlük indeksi değerinin 0.00'a yakın olması, maddeyi doğru cevaplayanların sayısının az olduğunu ve maddenin zor olduğunu ifade etmektedir. Bu bilgiler 1şı̆̆ııda testin bütününe bakıldığında testte yer alan maddelerin çoğunun madde güçlük indeksi değerinin 0.50'nin üzerinde, testin ortalama madde güçlük indeksinin ise 0.64 olması, testin genel anlamiyla öğrencilere kolay geldiğinin ve öğrencilerin kavrama düzeylerine uygun sorulardan oluştuğunun göstergesi niteliğinde olabilir.

Alanyazın incelendiğinde Fen Bilimleri dersine yönelik olarak geliştirilen testlerin ortalama madde güçlük indeksi değerlerinin 0.55 ve üzerinde olduğunu ifade eden çalışmalara rastlanmıştır (Açıkgöz ve Karsl1, 2015; Demir, Kızılay ve Bektaş, 2016). Ulaşılan bu sonuçlar geliştirilen başarı testinin ortalama madde güçlük indeksi değeri ile paralellik göstermektedir.

Testte yer alan maddelerin madde ayırt edicilik indeksi değerleri (d) 0.22 ile 0.74 arasındadır. Tekin (2010)'e göre geliştirilen başarı testinin madde ayırt edicilik indeksi değerinin 0.40 ve üzerinde olması, maddenin ayırt etme gücünün yüksek olduğunu ifade etmektedir. Testte yer alan maddelerin çoğunluğunun madde ayırt edicilik indeksi değerlerinin 0.40 ve üzerinde, testin ortalama madde ayırt edicilik indeksinin ise 0.50 olması, geliştirilen başarı testinin madde ayırt edicilik düzeyinin yüksek olduğunun göstergesi niteliğinde olabilir.

Alanyazın incelendiğinde Fen Bilimleri dersine yönelik olarak geliştirilen testlerin ortalama madde ayırt edicilik indeksi değerlerinin 0.40 ve üzerinde olduğunu ifade eden çalışmalara rastlanmıştır (Açıkgöz ve Karsl1, 2015; Demir, Kızılay ve Bektaş, 2016; Şener \& Taş, 2017). Ulaşılan bu sonuçlar geliştirilen başarı testinin ortalama madde ayırt edicilik indeksi değeri ile paralellik göstermektedir.

Geliştirilen Sistemler Başarı Testi’nin güvenirliğiyle ilgili olarak Cronbach Alpha katsayısı .83 olarak hesaplanmıştır. Can (2014), Cronbach Alpha katsayısının $0.00 \leq \alpha<0.40$ aralığında olmasını öğrencilerin testten aldıkları puanların güvenilir olmadığı, $0.40 \leq \alpha<0.60$ aralığında olmasını öğrencilerin testten aldıkları puanların düşük olduğu, $0.60 \leq \alpha<0.90$ aralığında olmasını öğrencilerin testten aldıkları puanların oldukça güvenilir olduğu, $0.90 \leq \alpha<1.00$ aralığında olmasını ise öğrencilerin testten aldıkları puanların yüksek güvenilirlikte olduğu şeklinde sınıflandırmıştır. Bu bilgiler 1şığında öğrencilerin testten aldıkları puanların oldukça güvenilir olduğu söylenebilir.

Alanyazın incelendiğinde geliştirilen testlerin Cronbach Alpha katsayılarının $0.60 \leq \alpha<$ 0.90 aralığında olduğunu ifade eden çalışmalara rastlanmıştır (Açıkgöz ve Karslı, 2015; Ayvacı ve Durmuş, 2016; Çakır ve Aldemir, 2011; Demir, Kızılay ve Bektaş, 2016; Saraç, 2018; Şener \& Taş, 2017). Ulaşılan bu sonuçlar geliştirilen başarı testinin Cronbach Alpha katsayısı ile paralellik göstermektedir.

\section{Öneriler}

Geçerli ve güvenilir bir başarı testi geliştirilmesinin amaç edinileceği çalışmalarda örneklem sayısı artırılarak, araştırmanın ortalamasının ve standart kaymasının evreni temsil etme oranı da artırılabilir.

Geliştirilen test vücudumuzdaki sistemler ünitesindeki solunum sistemi, dolaşım sistemi, destek ve hareket sistemi konu başlıklarına yönelik olup, hücre konusu çalışmaya dâhil edilmemiştir. Araştırmacıların aynı sınıf düzeyine ve üniteye yönelik ancak solunum sistemi, 
dolaşım sistemi, destek ve hareket sistemi konularının yanında hücre konusu da içeren, ünite odaklı başarı testleri geliştirmeleri önerilmektedir.

Çoktan seçmeli testlerin genellikle olgusal bilgiyi ölçmede etkili olması, problem çözme, yaratıcı ve eleştirel düşünme gibi üst düzey bilgi ve becerileri ölçmede yeteri kadar etkili olamaması, öğrencilerin testte yer alan maddelerin yokladıkları bilgilere sahip olmasalar dahi, tahmin yoluyla doğru cevabı bulma olasılıklarının olması gibi çeşitli nedenlerden dolayı geçerli ve güvenilir bir başarı testi geliştirmeyi amaçlayan araştırmacılara, bu süreçte çoktan seçmeli testler yerine iki ya da üç aşamadan oluşan çoktan seçmeli testleri kullanmaları önerilmektedir.

\section{Kaynakça}

Açıkgöz, M. \& Karslı, F. (2015). Alternatif ölçme-değerlendirme yaklaşımları kullanılarak iş ve enerji konusunda geliştirilen başarı testinin geçerlilik ve güvenirlik analizi. Amasya Üniversitesi Ĕ̆itim Fakültesi Dergisi, 4(1), 1-25.

Akbulut, H. İ. \& Çepni, S. (2013). Bir üniteye yönelik başarı testi nasıl geliştirilir? : İlköğretim 7. sınıf kuvvet ve hareket ünitesine yönelik bir çalışma. Amasya Üniversitesi Ĕ̈itim Fakültesi Dergisi, 2(1), 18-44.

Ayvacı, H. Ş. \& Durmuş, A. (2016). Bir başarı testi geliştirme çalışması: Isı ve sıcaklık başarı testi geçerlik ve güvenirlik araştırması. Ondokuz Mayıs Üniversitesi Ĕ̈itim Fakültesi Dergisi, 35(1), 87-102.

Bahar, M., Nartgün, Z., Durmuş, S., \& Bıçak, B. (2012). Geleneksel tamamlayıcı ölçme değerlendirme teknikleri (5. Baskı). Ankara: Pegem Akademi.

Başol, G. (2015). Eğitimde ölçme ve değerlendirme (Genişletilmiş 3. Baskı). Ankara: Pegem Akademi.

Başol, G., Çakan, M., Kan, A., Özbek, Ö. Y., Özdemir, D. \& Yaşar, M. (2013). Eğitimde ölçme ve değerlendirme. Ankara: Pegem Akademi.

Can, A. (2014). SPSS ile bilimsel araştırma sürecinde nicel veri analizi (2. Baskı). Ankara: Pegem A Yayıncilık.

Crocker, L. \& Algina, J. (1986). Introduction to classical and modern test theory. Harcourt Brace Jovanovich College Publishers.

Çakır, M. \& Aldemir, B. (2011). İki aşamalı genetik kavramlar tanı testi geliştirme ve geçerlik çalışması. Mustafa Kemal Üniversitesi Sosyal Bilimler Enstitüsü Dergisi, 8 (16), 335-353. 
Demir, N., Kızılay, E. \& Bektaş, O. (2016). 7. sınıf çözeltiler konusunda başarı testi geliştirme: Geçerlik ve güvenirlik çalışması. Necatibey Eğitim Fakültesi Elektronik Fen ve Matematik Ĕ̈itimi Dergisi, 10(1).

Ekiz, M. (2015). Model ve etkinliklerle desteklenen öğretim sürecinin sindirim sistemi konusundaki kavram yanılgıları ve bilgi eksiklikleri üzerindeki etkisi. Yüksek Lisans Tezi, Karadeniz Teknik Üniversitesi, Eğitim Bilimleri Enstitüsü, Trabzon.

Gönen, S., Kocakaya, S. \& Kocakaya, F. (2011). Dinamik konusunda geçerliği ve güvenirliği sağlanmış bir başarı testi geliştirme çalışması. Yüzüncü Yıl Eğitim Fakültesi Dergisi, 8(1), 40-57.

Gülçiçek, Ç. (2002). Lise 2. sınıf ögrencilerinin mekanik enerjinin korunumu konusundaki kavram yanılgıları. Yayınlanmamış Yüksek Lisans Tezi, Gazi Üniversitesi, Eğitim Bilimleri Enstitüsü, Ankara.

Gültekin, M. (2017). Program geliştirmeye ilişkin temel kavramlar, Behçet Erol ve Taha Yazar (Editörler). Eğitimde program geliştirme ve değerlendirme (1. Bask1). Ankara: Pegem Akademi.

Kan, A. (2006). Ĕgitimde ölçme ve değerlendirme. Ankara: Ertem Matbaası.

Kan, A. (2011). Ölçme aracı geliştirme, Satılmış Tekindal (Editör). Eğitimde ölçme ve değgerlendirme (3. Bask1). Ankara: Pegem Akademi.

Kenan, O. \& Özmen, H. (2014). Maddenin tanecikli yapısına yönelik iki aşamalı çoktan seçmeli bir testin geliştirilmesi ve uygulanması. Journal of Research in Education and Teaching, 3(3), 371-378.

Koray, Ö. \& Tatar, N. (2003). İlköğretim öğrencilerinin kütle ve ağırlık ile ilgili kavram yanılgıları ve bu yanılgıların 6., 7. ve 8. sınıf düzeylerine göre dağılımı. Pamukkale Üniversitesi Eğitim Fakültesi Dergisi Fen ve Matematik Ë̆itimi Özel Sayısı, (1) 13.

Küçükahmet, L. (2002). Öğretimde planlama ve değerlendirme (13. Baskı). Ankara: Nobel Yayın Dağıtım.

Ogan Bekiroğlu, F. (2004). Ne kadar başarılı? Klasik ve alternatif ölçme-değerlendirme yöntemleri ve fizikte uygulamalar (1. Baskı). Ankara: Nobel Yayın Dağıtım.

Öcal, E. (2014). Vücudumuzdaki sistemler ünitesinin öğretiminde drama yönteminin ve kukla/ karagöz uygulamalarının ögrenci başarısı ve tutuma etkisi. Doktora Tezi, Gazi Üniversitesi, Eğitim Bilimleri Enstitüsü, Ankara. 
Saraç, H. (2018). Fen Bilimleri dersi 'maddenin değişimi' ünitesi ile ilgili başarı testi geliştirme: Geçerlik ve güvenirlik çalışması. Abant İzzet Baysal Üniversitesi Eğitim Fakültesi Dergisi, $18(1), 416-445$.

Selvi, M. \& Yakışan, M. (2004). Üniversite birinci sınıf öğrencilerinin enzimler konusu ile ilgili kavram yanılgıları. Gazi Ĕ̆itim Fakültesi Dergisi, 24(2), 173-182.

Şener, N. \& Taş, E. (2017). Developing achievement test: A research for assessment of 5th grade biology subject. Journal of Education and Learning, 6(2), 254.

Şimşek, Ü. (2007). Çözeltiler ve kimyasal denge konularında uygulanan jigsaw ve birlikte öğrenme tekniklerinin öğrencilerin maddenin tanecikli yapıda öğrenmeleri ve akademik başarıları üzerine etkisi. Doktora tezi, Atatürk Üniversitesi, Fen Bilimleri Enstitüsü, Erzurum.

Talim ve Terbiye Kurulu Başkanlığı (TTKB) (2013). İlköğretim kurumları (ilkokullar ve ortaokullar) Fen Bilimleri dersi (3, 4, 5, 6, 7 ve 8. Sınıflar) öğretim programı. Ankara: Milli Eğitim Bakanlığı.

Tekin, H. (2010). Ĕgitimde ölçme ve değerlendirme (20. Bask1). Ankara: Yarg1 Yayınevi.

Turgut, M. F. (1977). Eğitimde ölçme ve değerlendirme metotları. Ankara: Nüve Matbaası.

Turgut, M. F. (1992). Ĕ̈itimde ölçme ve değerlendirme. Ankara: Saydam Matbaacılık.

Turgut, M. F. (1995). Ĕgitimde ölçme ve değgerlendirme metotları (10. Baskı). Ankara: Yargıcı Matbaas1.

Yıldırım, C. (1983). Eğitimde ölçme ve değerlendirme. Ankara: ÖSYM Eğitim Yayınları 7.

Yürük, N. \& Çakır, Ö. S. (2000). Lise öğrencilerinde oksijenli ve oksijensiz solunum konusunda görülen kavram yanılgılarının saptanması. Hacettepe Üniversitesi Eğitim Fakültesi Dergisi, 18(18), 185-191. 


\section{Sistemler Başarı Testi}

\section{Ek 1. Sistemler Başarı Testi}

Aşağıdaki çoktan seçmeli soruları üzerinde işaretleyerek yanıtlayınız.

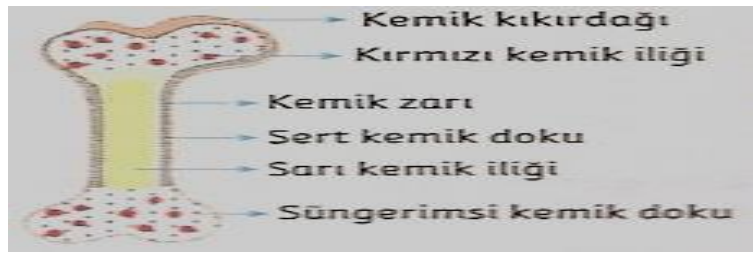

1) Yukarıdaki şekilde uzun kemiğin yapısını oluşturan bazı bölümler gösterilmiştir. Buna göre şekilde gösterilen bölümlerle ilgili aşağıdakilerden hangisi söylenemez?
A) Kemiğin uç kısmında kıkırdak bulunur.
B) Süngerimsi kemik dokusu içinde kırmızı kemik iliği bulunur.
C) Sert kemik boyuna büyümeyi sağlar.
D) Kemik zarı kemiğin enine büyümesini sağlar.

2) Nefes aldığımızda havanın vücudumuzda izlediği yol aşağıdakilerin hangisi gibidir?
A) Burun-girtlak-yutak-soluk borusu-bronş-bronşçuk-alveol
B) Burun-yutak-girtlak-soluk borusu-bronş-bronşçuk-alveol
C) Burun-gırtlak-soluk borusu-bronş-bronşçuk-yutak-alveol
D) Burun-yutak-bronş-soluk borusu-bronşçuk-alveol-gırtlak

3) Akciğerlerin yapısında bulunan alveollerin görevi aşağıdakilerden hangisidir?
A) Mikropları tutmak
B) Havayı nemlendirmek
C) Havayı ssitmak
D) Gaz değişimini sağlamak
4) Aşağıdaki yapılardan hangisinde düz kas bulunur?
A) Yemek Borusu kas1
B) Kol kas1
C) Göz kası
D) Parmak kas 1

5)

I. Alınan havanın nemlendirilmesini burun sağlar.

II. Soluk borusu zararlı maddeleri tutar.

III. Bronşlar akciğerlere hava taşır.

Solunum sisteminin yapı ve işleviyle ilgili, yukarıdaki bilgilerden hangileri yanlıştır?
A) I ve II
B) Yalnız III
C) I, II ve III
D) Hepsi

6) Aşağıdaki damarlardan hangisi temiz kan taşır? 

A) Akciğer toplardamarı
B) Akciğer atardamarı
C) Üst ana toplardamar
D) Alt ana toplardamarı

7)

I. Omurga

II. Kafatas 1

III. Uyluk kemiği

IV. Kalça kemiği

Yukarıda verilen kemik çeşitlerinden hangisi veya hangileri yassı kemiğe örnektir?
A) I ve II
B) II ve III
C) III ve IV
D) II ve IV

8)

I. Alyuvar mikroplarla savaşır.

II. Akyuvar kana kırmızı rengini verir.

III. Kan pulcukları kanın pıhtılaşmasını sağlar.

Banu kan hücreleri ve görevleri ile ilgili bildiklerini defterine yukarıdaki şekilde yazıyor. Yazılan notlar nasıl değiştirilirse Banu'nun yaptığı hata düzelir?
A) Alyuvar ve akyuvarın görevlerini değiştirmeli.
B) Kan pulcuklarının görevini kanın temizlenmesi olarak değiştirmeli.
C) Kan pulcukları ile Alyuvar görevlerini yer değiştirmeli.
D) Kan pulcukları ile akyuvar görevlerini yer değiştirmeli.

9) Aşağıda verilen uzun kemiğin kısımları ile yapı ve görevleri arasındaki ilişkilerin yer aldığı tabloda hangi iki öğrencinin cevapları değiştirilirse yanlışlık düzelir?

\begin{tabular}{|c|c|c|}
\hline Öğrenci & Kemiğin Kısımları & Yapı / Görevleri \\
\hline Ece & Kırmızı Kemik İliği & Enine büyümeyi sağlar \\
\hline Nurbanu & Süngerimsi Kemik & Gözenekli yapıdadır \\
\hline Zeynep & Kemik Zarı & Kan hücresi oluşturur \\
\hline Nisanur & Sarı kemik iliği & Yağ içerir \\
\hline
\end{tabular}
A) Ece - Nurbanu
B) Zeynep - Nisanur
C) Ece - Zeynep
D) Nisanur - Nurbanu

10) Dolaşım sistemimizle ilgili aşağıda verilenlerden hangisi yanlıştır?
A) Alyuvarlar kana kırmızı rengini verir.
B) İnsan kalbi iki odacıktan oluşur.
C) Büyük dolaşımın görevi hücrelere besin ve oksijen taşımaktır.
D) Aort bir atardamardir.

11) Destek ve hareket sistemimizin sağlığını korumak için aşağıdakilerden hangisini yapmamalıyı?
A) Dengeli beslenmek
B) Yeterince güneş 1şı̆̆ $1 \mathrm{almak}$ 

C) Dik durmak
D) Dizleri bükmeden yük kaldırmak

12)

Ayşe: Uyluk kemiği ve kafatası aynı kemik çeşididir.

Ali: Kalça kemiği kısa kemiktir.

Arda: El ve ayak parmak kemikleri uzun kemiklere örnektir.

Yukarıdaki öğrencilerin cümleleri hakkında aşağıdakilerden hangisi söylenebilir?
A) Ali ve Ayşe doğru, Arda yanlış
B) Üçü de doğru
C) Arda doğru, Ali ve Ayş̧e yanlış
D) Üçü de yanlış

\section{3)}

I. Ağızdan nefes almak

II. Dengeli beslenmek

III. Sigara içmek

IV. Burun kıllarını yolmak

Yukarıdaki maddelerden hangileri solunum sistemimizin sağlığını olumsuz etkiler?
A) Yalnız I
B) III ve IV
C) I, III ve IV
D) Yalnız III

14)

I. Süngerimsi kemik vardır.

II. Sarı kemik iliği vardır.

III. Kıkırdak dokuya sahiptir.

IV. Yassı kemiktir.

\section{Yukarıdaki özelliklerden hangileri baldır ve pazı kemiği için ortaktır?}
A) I, II ve III
B) III ve IV
C) II ve IV
D) Yalnız IV

15) Soluk alma sırasında aşağıdakilerden hangisi gerçekleșmez?
A) Kaburgalar arası kaslar kas1lır.
B) Diyafram kubbe şeklini alır.
C) Göğüs boşluğu hacmi genişler.
D) Oksijen alveollere gelir.

16) Bengisu koşarken düşmüşsür ve bacağı kanamıştır. Bir süre sonra kanama durmuştur. Bengisu'nun bacağındaki kanamanın durmasında hangi kan hücresi görev almıştır?
A) akyuvarlar
B) alyuvarlar
C) alveoller
D) kan pulcukları

17) Kalp ile ilgili olarak verilen aşağıdaki bilgilerden hangisi yanlıştır?
A) Kalp düzenli olarak kasılıp gevşeyerek kanı tüm vücuda pompalar.
B) Dört odacıklıdır.
C) Sağ tarafı temiz sol tarafi kirli kan ile doludur. 
D) Kulakçıklar kasılırken karıncıklar gevşer.

18) Kan ile dokular arasında madde alışverişini sağlayan damar çeşidi aşağıdakilerden hangisidir?
A) atardamar
B) k1lcal damar
C) toplardamar
D) aort

19)

I. Büyük dolaşımda oksijence fakir kan alveollere gider.

II. Küçük dolaşımda kan kalbin sol karıncığından akciğerlere gider.

III. Toplardamarlar kulakçıklara kanı getirir.

Yukarıda verilen ifadelerden hangileri doğrudur?
A) Yalnız III
B) II ve III
C) I ve III
D) I, II ve III

20) Aşağıdakilerden hangisi dolaşım sistemi hastalıklarının tedavisinde kullanılan yöntemlerden değildir?
A) Diyaliz
B) Kalp pili
C) Anjiyo
D) Kalp nakli

21) Büyük kan dolaşımında sol karıncıktan çıkan temiz kan kalbin hangi odacığından geri döner?
A) sol kulakçık
B) săg kulakçık
C) sağ karıncık
D) sol karıncik

22)

I. Verem

II. Varis

III. Anemi

IV. Tansiyon

Yukarıdakilerden hangileri dolaşım sistemi hastalıklarındandır?
A) II ve III
B) III ve IV
C) I, II ve III
D) II, III ve IV

23)
Ali:- Ayşe'den
kan alabilirim ama Fatma'dan
alamam. Burak:- Ben Ali'den, Ayşe'den ve Fatma'dan kan alabilirim.

Fatma'nın kan grubu B Rh + olduğuna göre, yukarıda verilen bilgilere göre Ali, Burak ve Ayşe'nin kan gruplarm bulunuz.

A)

\begin{tabular}{|l|l|l|}
\hline Ali & Ayşe & Burak \\
\hline $\mathrm{ARh}+$ & $\mathrm{B} \mathrm{Rh}+$ & $\mathrm{ORh}+$ \\
\hline $\mathrm{ARh}+$ & $\mathrm{ARh}+$ & $\mathrm{B} \mathrm{Rh}+$ \\
\hline $\mathrm{B} \mathrm{Rh}+$ & $\mathrm{ARh}+$ & $\mathrm{AB} \mathrm{Rh}+$ \\
\hline $\mathrm{ARh}+$ & $\mathrm{ARh}+$ & $\mathrm{AB} \mathrm{Rh}+$ \\
\hline
\end{tabular}

